\title{
KEGIATAN TEKNIS DI PERPUSTAKAAN POLI TEKNIK KEMENTERIAN KESEHATAN MATARAM
}

TECHNICAL ACTIVITIES AT MATARAM MINISTRY OF HEALTH POLYTECHNIC LIBRARY

\author{
Lalu Amirul Khairi ${ }^{1}$, Lubis ${ }^{2}$, Abdul Hafiz ${ }^{3}$ \\ ${ }^{1,2,3}$ Universitas Muhammadiyah Mataram \\ ${ }^{2}$ Email: lubis.vharoso@gmail.com \\ ${ }^{3}$ Email: abdulhafiz1971da@gmail.com
}

\begin{abstract}
ABSTRAK/ ABSTRACT
Perpustakaan juga sangat berperan penting dalam menumbuhkan minat baca pada masyarakat. Namun dalam hal ini pusrtakawan, orang tua juga tenaga pendidik harus bekerja sama dalam memperkenalkan perpustakaan sejak dini. Contohnya pada mahasiswa perkuliahan, ketika seorang mahasiswa memiliki niat membaca yang tinggi maka mereka akan sangat bersemangat untuk terus aktif dalam mengikuti masa perkuliahan. Oleh sebab itu, disini seorang pustakawan lebih berperan penting dalam mengajak para mahasiswa untuk datang dan membaca buku walau hanya beberapa menit saja, atau bisa dengan bantuan dosen yang memberikan tugas kepada mahasiswa yang berkaitan dengan masalah perpustakaan. Sehingga perlu diadakannya kegiatan pengabdian masayarakat untuk kegiatan teknis perpustakaan Politeknik Kementrian Kesehatan Mataram. Target khusus yang diharapkan tercapai adalah perbaikan kualitas pelayanan teknis sehingga membantu pemustaka dalam mempermudah menemukan informasi. Adapun metode yang digunakan untuk mencapai tujuan tersebut adalah dengan cara melakukan kegiatan teknis di perpustakaan. Semua tahapan kegiatan pengabdian masyarakat di Politeknik Kementrian Kesehatan Mataram telah 100\% dilaksanakan dan menghasilkan luaran diantaranya yaitu (1) Adanya aplikasi slims yang telah digunakan di Perpustakaan Poltekkes Kemenkes Mataram sehingga dapat membantu meningkatkan kualitas pelayanan perpustakaan (2) Kegiatan ini juga dapat memudahkan pengguna perpustakaan saat mencari bahan pustaka dan dapat mempermudah pustakawan dalam mengelola perpustakaan secara otomatis.
\end{abstract}

Kata Kunci : Perpustakaan, Pelaanan Teknis, Pengeloaan Perpustakaan

Submited : 25 Oktober 2021

Revision : 29 Oktober 2021

Accepted : 5 November 2021

$* * * * *$

\section{A. PENDAHULUAN}

Perpustakaan di era moderen ini bukan seperti penilaian sebelumnya.Jadi dulu orang-orang beranggapan bahwa perpustakaan itu adalah tempat berkumpulnya buku-buku lama yang bahkan tidak menarik untuk dikunjungi, namun tidak untuk sekarang.Sekarang perpustakaan sangatlah dibutuhkan oleh orang-orang seperti 
siswa, mahasiswa, guru, dosen dan masyarakat juga membutuhkannya, karena merupakan sumber informasi yang paling banyak diminati dan terpercaya.

Perpustakaan dijadikan sebagai pusat sumber daya informasi serta menjadi jantung menuju suatu lembaga atau instansi, baik yang berkaitan dengan pendidikan, pembelajaran, dan penelitian. Perpustakaan juga dituntut untuk menyediakan segala macam informasi karena pemaainya banyak yang berada dikalangan akademis sehingga kebutuhan akan informasi sangat akurat. Sejak awal perpustakaan didirikan sudah mempunyai tujuan, yakni mencerdaskan kehidupan bangsa dan menjadikan masyarakat yang berpendidikan lebih baik untuk dipercaya.

Perpustakaan juga sangat berperan penting dalam menumbuhkan minat baca pada masyarakat. Namun dalam hal ini pusrtakawan, orang tua juga tenaga pendidik harus bekerja sama dalam memperkenalkan perpustakaan sejak dini. Contohnya pada mahasiswa perkuliahan, ketika seorang mahasiswa memiliki niat membaca yang tinggi maka mereka akan sangat bersemangat untuk terus aktif dalam mengikuti masa perkuliahan. Oleh sebab itu, disini seorang pustakawan lebih berperan penting dalam mengajak para mahasiswa untuk datang dan membaca buku walau hanya beberapa menit saja, atau bisa dengan bantuan dosen yang memberikan tugas kepada mahasiswa yang berkaitan dengan masalah perpustakaan.

Perpustakaan sebagai sumber informasi juga berperan penting dalam membangun karakteristik mahasiswa dalam mempelajari ilmu pendidikan perpustakaan sebagai sumber informasi yang dituntun untuk memberikan layanan informasi yang lengkap, cepat, jelas, dan tepat guna mendapatkan pertanggung jawaban akan sumbernya. Keberadaan perpustakaan akan bernilai baik dan bermanfaat jika dikelola oleh ahli yang professional atau pustakawan itu sendiri. Seorang pustakawan adalah latar belakang pendidikan dalam bidang ilmu perpustakaan.

Perpustakaan yang berkembang sangat tinggi sekarang ini di pergunakan sebagai salah satu pusat informasi, sumber ilmu pengetahuan, penelitian rekreasi, pelestarian, budaya bangsa, serta memberikan jasa layanan lainnya pada pemustaka. 


\section{B. METODE}

Pelaksanaan kegiatan ini dilaksanakan di Politeknik Kementrian Kesehatan Mataram. Waktu pelaksanaan mulai tanggal 16 Maret 2021 hingga 30 April 2021 atau selama 1,5 bulan. Metode yang digunakan dalam melakukan kegiatan ini dengan terjun langsung terlibat dalam kegiatan pelayanan di Politeknik Kementrian Kesehatan Mataram.

\section{HASIL DAN PEMBAHASAN}

Politeknik Kesehatan Kemenkes Mataram terdapat perpustakaan dimana perpustakaan adalah salah satu unit penunjang teknis di bidang perpustakaan yang berada dibawah koordinasi PD III dan bertanggung jawab langsung kepada Direktur. Politeknik Kesehatan Kemenkes Mataram sendiri memiliki tiga lokasi yang berbeda yaitu di kampus A (Jurusan Keperawatan dan Kebidanan mataram), Kampus B (Jurusan Gizi dan Analis Kesehatan Mataram) dan Kampus C (Prodi Keperawatan Bima). Unit perpustakaan mempunyai tugas memberi layanan bahan pustaka untuk keperluan pendidikan, penelitian dan pengabdian kepada masyarakat. Perpustakaan Politeknik Kesehatan Kemenkes Mataram mempunyai kedudukan dan tugas pokok sebagai berikut :

a. Penyediaan dan Pengelolahan Bahan Pustaka

b. Pemberian Layanan Referensi dan Pendayagunaan Bahan Pustaka

c. Pemeliharaan Bahan Pustaka

d. Pengembangan Perpustakaan

Seiring dengan berkembangnya zaman Perpustakaan Poltekkes Kemenkes Mataram yang semulanya menggunakan alat manual kini pegawai terus meningkatkan perkembangan perpustakaannya supaya menjadi perpustakaan yang lebih baik, berkembang dan dapat meningkatkan minat baca para mahasiswamahasiswi di Poltekkes Kemenkes Mataram.

Selain kitu Perpustakaan Poltekkes Kemenkes Mataram juga sudah mengguanakan sistem aplikasi digital yang dimana sistem digital ini disebut dengan slims( Senayan Library Managemen System)yang dapat dengan mudah mengolah data-data koleksi yang ada di perpustakaan.selain itu dengan adanya slims ini pustakawan atau pegawai dapat mempercepat waktu pegawai sehingga pekerjaan 
lebih efektif dan pegawai dengan mudah mengolah bahan perpustakaan.dengan itu pustakawan bisa lebih focus lagi untuk melakukan pengembangan-pengembangan perpustakaan supaya menjadi lebih bagus lagi.

\section{Pengolahan Bahan Pustaka}

Pengolahan adalah pekerjaan yang dimulai sejak koleksi diterima di perpustakaan sampai dengan penempatan di rak atau ditempat tertentu yang telah disedialkan Sutarno (2006:179). Menurut Sutarno (2006: 151) mengatakan bahwa pengolahan koleksi perpustakaan merupakan serangkaian pekerjaan yang dilakukan sejak bahan pustaka diterima oleh perpustakaan sampai dengan siap dipergunakan oleh pemakai, tujuannya agar semua koleksi dapat ditentukan atau ditelusuri dan dipergunakan dengan mudah oleh pemakai.

Yang dimaksud dengan pengolahan bahan pustaka adalah kegiatan yang di lakukan sejak perpustakaan masuk ke perpustakaan sampai siap untuk di manfaatkan atau di pinjam oleh pemakainya. Kegiatan yang di lakukan di antaranya adalah:

\section{a. Invetarisasi}

Inventaris adalah pencatatan bahan pustaka baik yang di dapat dari pembelian hadiah dan tukar menukar dalam buku induk. Tujuan inventaris buku dalam kegiatan pencatatan buku induk perpustakaan Poltekkes Kemenkes Mataram meliputi :

1) Nama pengarang

2) Judul buku

3) Tahun terbit

4) Edisi keberapa

5) Nama penerbit

6) Tempat dan tahun terbit

7) Sumber buku (pembelian, hadiag, atau sumbangan)

Selama melakukan kegiatan PKL kegiatan yang dilakukan di perpustakaan yaitu mengolah bahann pustaka digital dan mencetak label, barkot selain itu kita juga mencatat atau menginfut jumlah buku secara benar sesuai dengan ketentuan dan peraturan yang berlaku di peerpustakaan. 


\section{b. Klasifikasi}

Klasifiasi adalah pengelompokan secara sistematis dari pada sejumlah objek gagasan atau benda-benda lain ke dalam kelas atau golongan tertentu berdasarkan ciri-ciri yang sama bahwa pengelompokan koleksi perpustakaan (Hamakonda, 2014-31) yaitu :

1) Pengelompokan atau klasifikasi artikel yang artinya sistem pengelompokan koleksi berdasarkan ukuran, warna, atau data fisik lainnya.

2) Pengolahan klasifikasi fundamental artinya pengelompokan berdasarkan subjek tertentu.

Dengan adanya perkembangan klasifikasi pada dasarnya yang paling digunakan diperpustakaan perguruan tinggi dan sekolah sekarang adalah adanya pembagian disiplin ilmu berdasarkan subjek tertentu, didtukung dengan adanya petunjuk yang dibuat Dewey Desmial Classification (DDC) dimana dewey disilin ilmu pengetahuan menjadi 10 disiplin ilmu antara lain :

a) Tujuan klasifikasi

Menentukan koleksi bahan pustaka didalam jajaran koleksi perpustakaan sehingga memudahkan temu kembali informasi

* Mengumpulkan semua bahan pustaka yang dimiliki subjek yang sama dengan suatu jajaran koleksi

b) Manfaat

Untuk mengetahui bahan pustaka dan keseimbangan koleksi yang dimiliki perpustakaan

Untuk mengetahuai kecakupan ilmu pengetahuan

Sebelum menentukan nomor kelas buku yang akan di klasifikasi terlebih dahulu kita menentukan tujauan subjeknya. Ada beberapa cara yaitu:

Melalui judul buku

Melalui daftar isi

Melalui daftar bahan bacaan (dafrat pustaka)

Membacaa sebagaian atau keseluruhan bahan pustaka Menyakan pada ahlinya

Contohnya:

Judul buku: pendidikan bahasa Indonesia untuk perguruan tinggi 
Tajuk subjek bahasa Indonesia-pendidikan

No. klasifikasinya: 410.7

Diamati dari koleksi-koleksi yang ada pada perpustakaan, dimana sebagaian koleksi audah diberi nomor kelas pada bahan pustaka di perpustakaan Sma Negeri 2 Mataram menggunakan buku Dewey Desimal Clasifitation (DDC) Ringkas Edisi Ke-14 dari perpusnas dan persepuluhan Tawo P. Hamakonda.

\section{c. Memberi label daan barkot pada buku}

Pemberian label dan barkot bertujuan untuk memberikan tanda pada buku dan dapat memudahkan pengunjung untuk menemukan atau juga menandakan kepemilikan Perpustakaan Poltekkes Kemenkes Mataram, biasanya label yang sudah di print akan di temple di punggung buku dengan menggunakan lem yang sudah di tentukan, untuk menempel barkot biasanya ditempel dibagian belakang muka buku. Pemberian label dengan cara menempel di punggung buku setelah melakukan penginputan data.

\section{d. Shelving}

Kegiatan shelving dilakukan untuk mempermudah pemustaka dan pustakawan dalam temu Kembali informasi terutama buku. Menyusun kembali buku yang sudah di tempelkan label dan barkot ke rak yang sesuai dengan kelas masing masing dari buku tersebut.

\section{Pengolahan Bahan Pustaka menggunakan SLiMs}

Adapun kegiatan yang dilakukan selama melakukan PKL

a. Pengolahan bahan pustaka

Disini akan di bahas cara mengakses software SLIMS 8 menggunakan XAMPP, adapun langkah-langkah daam mengakses software SLIMS 8 adalah sebagai berikut :

1) Buka XAMPP control panel

2) klik piihan start yang berada disebelah kanan menu apache, tujuannya adalah untuk mengaktifkan fitur webserver Local/Localhost pada computer 
3) Klik pilihan start yang berada di sebelah kanan Menu Mysql yang bertujuan untuk mengaktifkan akses Database Mysql yang tersedi

4) Tutup jendela XAMPP, kemudian buka aplikasi Mozila

5) Pada address bar masukkan link http://Localhost/slims8

6) Selanjutnya masukkan user name dan password untuk masuk ke menu slims 8.

7) Setelah itu klik menu Bibliography dan akan muncul sub menu daftar bibliography(disini terdapat jumlah buku-buku yang sudah di imput) dan tambah bibliography baru(menu yang digunakan untuk mengimput bukubuku yang ingin di imput)

8) Klik sub menu tambah bibliography baru untuk menambahkan atau mengimput buku

9) Pada sub menu tambah bibliography baru ini akan munjul beberapa data yang harus diisi seperti judul, pengarang, edisi, ISSN/ISBN, penerbit, tahun terbit, tempat terbit, deskripsi fisik, judul seri, klasifikasi, no panggil, subjek dan gambar buku

10) jika sudah diisi semua data yang tersedia maka klik simpan

11) Kemudia klik sunting untuk memperbaharui dan menambahkan kode eksemplar buku

12) setelah itu klik menu tambah kode eksamplar untuk menambahkan kode eksamplar bukunya

13) Pada kode eksemplar pun harus mengisi beberapa data di antaranya kode eksamplar, no panggil, kode infentaris, lokasi rak

14) Setelah itu klik perbaharui

15) untuk memastikan bahwa buku tersebut telah terimput atau belum bisa di lihat dengan cara mengklik menu daftar bibliography maka akan muncul semua buku yang terimput disana.

\section{b. Labeling}

Label buku berfungsi untuk memudahkan pemakai dalam mencari nomor klasifikasi, karena label buku di tempelkan pada punggung buku. Label buku berisi nomor klasifikasi, 3 (tiga) huruf nama penggarang di balik, 1 (satu) huruf awal judul buku. Label buku tersebut dari dibuat dari kertas 
persegi kecil dengan ukuran tertentu ditempelkan pada pengguna buku kirakira $3 \mathrm{~cm}$ dari bawah.

Adapun langkah-langkah dalam mencetak label buku adalah:

1) Pilih menu bibliography yang tertera pada menu utama

2) Pilih menu pencetakan label yang tertera pada menu yang berada disebelah kiri bawah.

3) Pilih nama bahan pustaka yang akan dibuatkan label, pilih menu tambahan dalam antrian, kemudian pilih cetak label dari daftar terpilih

4) Setelah itu akan muncul Print preview, lalu piih menu print dan label siap untuk di print.

c. Mencetak Barcode Buku

Adapun langkah-langkah dalam mencetak barcode buku adalah:

1) Pilih menu bibliography yang tertera pada menu utama

2) Pilih menu pencetakan barcode yang tertera pada menu yang berada disebelah kiri bawah

3) Pilih nama bahan pustaka yang akan dibuatkan ukuran barcode, pilih menu tambahan dalam antrian, kemudian pilih cetak barcodel dari daftar terpilih

4) Setelah itu akan muncul Print preview, lalu piih menu print dan barcode buku siap untuk di print.

\section{SIMPULAN}

Adapun kesimpulan terkait kegiatan pengabdian pada Perpustakaan Politeknik Kesehatan Kemenkes Mataram yaitu dengan adanya aplikasi slims yang telah digunakan di Perpustakaan Poltekkes Kemenkes Mataram dapat membantu meningkatkan kualitas pelayanan perpustakaan. Kegiatan ini juga dapat memudahkan pengguna perpustakaan saat mencari bahan pustaka dan dapat mempermudah pustakawan dalam mengelola perpustakaan secara otomatis. 


\section{DAFTAR PUSTAKA}

Hamakonda, Towa P., (2014). Pengantar Klasifikasi Persepuluhan Dewey. Jakarta: Gunung Mulia

Sutarno, NS. (2006). Perpustakaan dan Masyarakat. Jakarta: Sagung Seto 